\title{
EUTROPHICATION ASSESSMENT OF COASTAL WATERS BASED ON INDICATORS: A LITERATURE REVIEW
}

M. KARYDIS

Received: 09/02/09

Accepted: 26/03/09

\author{
Department of Marine Sciences \\ University of the Aegean \\ GR81100, Mytilini, Greece
}

\begin{abstract}
Numerous methods have been developed for the quantitative assessment of eutrophication: statistical techniques, simulation models and water quality indicators are the most widely used techniques to assess trophic levels. All these methods share a common goal: to evaluate the environmental impact due to high nutrient concentrations / phytoplankton biomass and classify the waters into oligotrophic, mesotrophic and eutrophic water types. This classification provides a useful tool for assessing environmental quality and help coastal managers and planners in the decision making. In the present work the indicators used for eutrophication assessment are reviewed. They provide useful information because voluminous amounts of data can be expressed through a single number. Variable indices such as chlorophyll and nutrient concentrations, phytoplankton biomass and water transparency are examined and ranges defining levels of eutrophication are proposed. Among the flux measurements, primary productivity has also been considered as an indicator useful in assessing trophic levels and a productivity scaling is also given. Community indices and their application in eutrophication studies are overviewed and their effectiveness in describing eutrophic trends is evaluated; their assumptions, advantages and shortcomings are also discussed. Among the twelve community indices evaluated for assessing eutrophication, only four were found to respond to eutrophic conditions; in nutrient and phytoplankton variables used as indicators, their frequency distribution showed overlapping between water types; this seems to be a problem in defining boundary values discriminating trophic levels. As the indices express ecosystem status and conditions, if they are going to be used under the Water Framework Directive, special consideration is needed since different scales seem to apply at regional level rather than forming a universal tool applicable to all European coastal waters.
\end{abstract}

KEYWORDS: Trophic status, Eutrophication Indices, Marine Pollution, Aegean Sea, Eastern Mediterranean.

\section{INTRODUCTION}

Eutrophication is the most studied form of coastal marine pollution (Rodhe, 1969; Hooper, 1969; Vollenweider et al., 1992). Eutrophic waters are characterized by excessive algal growth as a consequence of nutrient enrichments of coastal surface waters. This problem, that is high nutrient concentration and algal biomass is commonly called eutrophication from

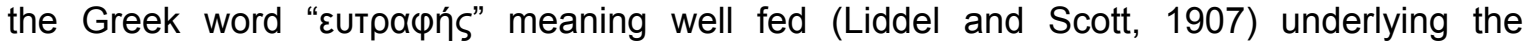
excessive algal growth. If the coastal waters are nutrient poor with low productivity are characterized as "oligotrophic" whereas, nutrient rich waters with high algal biomass are characterized as "eutrophic". The intermediate conditions characterize "mesotrophy". The impacts of eutrophication in the marine environment vary according to the enrichment level: slight increase of phytoplankton biomass is followed by changes in community structure. More serious impacts decrease the water transparency and accumulation of organic matter is observed due to the uncoupling between nutrient supply and use; at this stage harmful algal 
blooms can appear as well as opportunistic macroalgae. Hypoxia or even anoxia is the last stage of eutrophication (Gray, 1992); this phase is often characterized as dystrophic.

The quantitative assessment of eutrophication is not an easy approach although the cause effect variables of the phenomenon are well defined and the dynamics of eutrophication have been well understood a long time ago (Dugdale, 1967). Although the parameters involved can be easily measured on a routine basis, there is a number of shortcomings related to the problem of quantifying eutrophic conditions (Karydis, 2001; Primpas and Karydis, 2009): (a) it is difficult to discriminate between the nutrients of the system and nutrients from human activities i.e. discrimination between natural and anthropogenic sources (b) the phenomenon is described by a number of variables such as nitrate, nitrite, ammonia, phosphate, chlorophyll, phytoplankton biomass and water transparency; most of these variables are interrelated (c) variable distribution deviates from normality (d) the annual cycle of nutrients and phytoplankton induces wide and overlapping ranges in the parametric values. Additional difficulties also arise from the algorithms used during processing of the data (Primpas et al., 2008).

Many indices have been proposed for the classification of coastal waters into oligotrophic, mesotrophic and eutrophic water types since they have the merit of summarizing extensive and voluminous field information. Abiotic indices are usually based on nutrient values; the N/P ratio in a given body of water has been used to define eutrophic conditions (Ryther and Dunstan, 1971). Nutrient algorithms designed to assess trophic status has also been reported (Karydis et al., 1983) and nutrient variables have also been suggested as indicators of trophic conditions (Giovanardi and Tromellini, 1992; Ignatiades et al., 1992; Stefanou et al., 2000). Similar information has been given regarding chlorophyll concentrations (Kitsiou and Karydis, 2001). Phytoplankton cell number is also an indicator for assessing trophic status (Kitsiou and Karydis, 1998), although the cell number is influenced by both intrinsic and external factors (Valiela, 1984).

The use of ecological indicators describing species richness and species diversity as pollution indicators has been introduced by many workers since seventies (Bechtel and Copeland, 1971; Archibald 1972; Cook, 1976). These indicators provide information on the community structure (Pielou, 1984; Magurran, 2004; Ludwig and Reynolds, 1988) and can be influenced by environmental factors (Legendre and Legendre, 1983; Washington, 1984). Diversity indices have also been proposed by Mihnea (1985) on the ground that diversity values decrease as productivity increases. Similar views have been expressed with reference to pollution (Wilhm, 1967) that the severity of pollution is inversely proportional to species diversity; however, there was no clear scaling as to index ranges for the different levels of eutrophication. A more systematic investigation concerning the evaluation of 12 ecological indices for assessing eutrophic levels was performed by Karydis and Tsirtsis (1996) using historical data. Only four out of the twelve indices showed consistency in expressing eutrophic levels. However, there was no clear scaling as to index ranges for the different levels of eutrophication. The sensitivity of the indices to discriminate eutrophic levels based on statistical tests was also investigated (Tsirtsis and Karydis, 1998). A trophic index (TRIX) characterizing eutrophic levels, was introduced by Vollenweider et al. (1998): this is a multimetric index, combination of four variables related to eutrophication. This index has been scaled and used routinely for assessing the coastal water quality of Italian waters.

The main objective of the present work is to review the indices used for assessing trophic levels. In addition, reference values of the variables related to eutrophication are also provided.

\section{DEFINITIONS OF EUTROPHICATION: VARIATION OF THE THEME?}

Eutrophication is a well established relationship between nutrient concentrations and increase of phytoplankton biomass. However, a number of definitions has been proposed by various authors and authorities.

An early definition has been given by Steele (1974): "Eutrophication is the increase of the growth rate of algae, following a faster rate of nutrients in the marine environment as well as the consequences" 
According to Vollenweider (1992): "Eutrophication - in its more generic definition that applies to both fresh and marine waters - is the process of enrichment of waters with plant nutrients, primarily nitrogen and phosphorus that stimulates aquatic primary production and in its more serious manifestations leads to visible algal blooms, algal scums, enhanced benthic algal growth of submerged and floating macrophytes"

A shorter definition has been given by Gray (1992): Eutrophication occurs "when nutrients are added to the body of water they load, provided that they are not toxic compounds and provided that there is sufficient light to increased autotroph growth and also to increased heterotroph growth"

The definition of eutrophication proposed by OSPAR (2003) combines enrichment and algal growth with ecosystem disturbance: "Eutrophication means the enrichment of water by nutrients causing an accelerated growth of algae and higher forms of plant life to produce an undesirable disturbance to the balance of organisms present in the water and the quality of the water concerned..."

The definition proposed by UNEP emphasizes the contribution of organic matter: "Eutrophication is defined as an environmental disturbance caused by excessive supply of organic matter UNEP(DEC)MEDWG.231/14".

According to the definition given by Nixon (1995): "Eutrophication is an increase in the rate of supply of organic matter to an ecosystem" The author claims that definition shows a number of merits: (a) it short and simple (b) it does not mix causes and consequences (c) it is limited to the main process that is biomass production.

Although all definitions "agree" that eutrophication is the increase of algal material, they differ as far as the emphasis is concerned, on the impacts. The most comprehensive definition of eutrophication has been given by Vollenweider (1992) listing most of the disturbances. On the other hand Gray (1992) excludes the presence of toxic compounds. It is a rather unusual approach the UNEP definition since eutrophic trends are also induced by inorganic nutrients such as agricultural fertilizers. All the definitions mentioned above agree at one point: they consider eutrophication as a "disturbance" and not as a form of pollution.

\section{ECOSYSTEM DISTURBANCE: PHASES OF EUTROPHICATION}

Once a water body has been characterized as eutrophic, the deviation from "healthy conditions" can be assessed from different points of view included in the definitions given in the previous section: this water body is considered as "sensitive" under the EU Urban Waste Water Treatment Directive; "nitrate polluted" according to the Nitrates Directive and a "disturbed ecosystem" according to OSPAR (2001).

Like eutrophication, there are several definitions on ecosystem but the emphasis in all of them is on linking together the biotic community and the abiotic conditions in which organisms live. The meaning of the ecosystem includes considerations of the ways populations interact with each other and the abiotic environment to interact with each other and perpetuate the entire grouping (Pianka, 2000). The term "healthy ecosystem" is attributed to an unimpacted ecosystem. A "healthy" ecosystem is the ecosystem that functions well and is able to resist or recover from disturbance (Costanza, 1992). Such an ecosystem is characterized by vigor, organization, resistance and resilience. The vigor of the ecosystem refers to the ability of the biotic components to "recover" from impacts. The organization of the ecosystem refers to the food web and the biodiversity; ecosystem resistance is the non-response, up to a certain extent, of impacts such as nutrient enrichments. The ecosystem resilience refers to the ecosystem ability to survive through the applied pressures. Although all these ecosystemic characteristics contribute to the ecosystem health and integrity, they induce a non-linear response to the ecosystem which complicates the quantification of the assessment. The initial effects from eutrophication are negligible as they are below the carrying capacity: any measurable effects are less pronounced than seasonal fluctuations and therefore, any assessment seems to be dubious. As the phenomenon of eutrophication is getting established, changes in mean nutrient and chlorophyll concentrations as well as changes in the community structure become obvious. This stage can be the "early warning" for the ecosystem quality. 
However, a difficult question rises: what are the reference values used for comparisons? What are the threshold values characterizing a water body that gets into eutrophic phases? Nutrient, chlorophyll and phytoplankton biomass variables are ecosystem variables showing significant spatial and seasonal fluctuation. These two questions i.e. reference values and eutrophication scaling with emphasis on eastern Mediterranean waters will be addressed below.

\section{REFERENCE VALUES: A SEARCH FOR OLIGOTROPHIC REGIMES}

Discrimination between naturally occurring nutrients and human-induced nutrient enrichments in coastal environment is not always possible (OECD, 1982). Unimpacted ecosystems can be used as reference sites for comparing variable values related to eutrophication. Systems characterized by lack of man made environmental impacts are the oligotrophic systems (Vounatsou and Karydis, 1991). Although the main water body of eastern Mediterranean is oligotrophic, the bulk of data is rather limited since most studies are connected with coastal pollution problems. In the present section nutrient, chla and water transparency reference values mainly from the Aegean Sea and Eastern Mediterranean water bodies are reviewed (Vounatsou and Karydis, 1991; Ignatiades, 1998; Ignatiades, 2005; EEA, 2005).

The oligotrophic character of the Eastern Mediterranean Sea has been indicated by many authors (Kimor and Wood, 1975; Ignatiades, 1976; Krom et al., 1991; Ignatiades et al., 1995; Souvermezoglou et al., 1999; Gotsis-Skretas et al., 1999). The water body is characterized by low nutrient levels, improverished phytoplankton populations and low primary productivity. According to Krom et al. (1991) phosphorus is the limiting nutrient in the Eastern Mediterranean Basin. Low nitrate and phosphorus concentrations measured in 1993 ranged from $0,01-5 \mu \mathrm{M}$ and $0.00-17 \mu \mathrm{M}$ respectively; these low concentrations cannot support algal growth. Chla concentrations rarely exceeded $0.5 \mathrm{mg} \mathrm{m}^{-3}$ (Souvermezoglou et al., 1999). Nutrient ranges in the South Aegean ranges from 0.011 to $0.077 \mu \mathrm{M}$ for $\mathrm{P}_{-} \mathrm{PO}_{4}, 0.087-1.900$ $\mu \mathrm{M}$ for $\mathrm{N}-\mathrm{NO}_{3}, 0.010-098 \mu \mathrm{M}$ for $\mathrm{N}-\mathrm{NO}_{2}$, indicating the oligotrophic conditions prevailing in the South Aegean Sea (Ignatiades, 1998). Low values were also recorded on primary productivity: photosynthetic rates ranged from $0.135-0.143 \mathrm{mg} \mathrm{Cm}^{-3} \mathrm{~h}^{-1}$ in the upper $10 \mathrm{~m}$ and from 0.109 to $0.074 \mathrm{mg} \mathrm{Cm}^{-3} \mathrm{~h}^{-1}$ in the lower layer $(20-50 \mathrm{~m})$. In the same water body chl $\alpha$ values ranged from 0.099 to $0.128 \mathrm{mg}$ chla $\mathrm{m}^{-3}$ and the spring - winter maxima were 0.163 $\mathrm{mg} \mathrm{m}^{-3}$ and the summer autumn minima $0.043-0.040 \mathrm{mg} \mathrm{m}^{-3}$. There also records on oligotrophic baseline information in the South East Aegean Sea. During the period 1983-1985 (Ignatiades et al., 1995) the annual ranges of phosphates were $0.01-0.53 \mu \mathrm{g}$-at $\mathrm{L}^{-1}$, nitrates 0.02-0.7 $\mu \mathrm{g}$-at $\mathrm{L}^{-1}$ and ammonia 0.04-2.26 $\mu \mathrm{g}$-at $\mathrm{L}^{-1}$ (Table 1 ). Chla values maxima in the same area ranged from 0.27 to $0.25 \mathrm{mg} \mathrm{Chla} \mathrm{m}^{-3}$ and minima $0.07-0.09 \mathrm{mg} \mathrm{Chla} \mathrm{m}^{-3}$. Phytoplankton abundance was $1.0 \times 104-6.3 \times 104$ cells L $^{-1}$ and $2.1 \times 103-7.7 \times 103{\text { cells } L^{-1}}^{-1}$ respectively. The Secchi disk depth in most cases varied between 25 and $40 \mathrm{~m}$; the observed very high transparency of the water body is also indicative of Secchi values characterizing oligotrophic waters.

\section{INDICATORS: A BRIEF OVERVIEW}

Modern approaches in coastal management and development assume quantification of economic social and environmental trends. Decision support systems (Janssen, 1992) are used to get a quantitative measure according to the priorities set; this processing cannot be performed with raw data and therefore requires the "condensation of the information" into single numbers "the indicators" or "indices". This management concept has led European Environmental Agency (EEA, 2005) to compare 37 indicators classified as structural indicators, sustainable development indicators and OECD environmental indicators. The EEA defines that "an indicator is a measure, generally quantitative, that can be used to illustrate and communicate complex phenomena simply, including trends and progress over time". The environmental indicators concerning water quality, are species diversity, nutrient and chla concentrations and bathing water quality in coastal and transitional waters. In addition, the Water Framework Directive (WDF 2000/60/EC) encourages the use of indicators for assessing 
Table 1. Reference values of some variables related to eutrophication assessment from oligotrophic water bodies

\begin{tabular}{|c|c|c|c|}
\hline Variable & Values & Sampling area & Source \\
\hline Phosphates & $\begin{array}{l}0.04-0.06 \mu \mathrm{g} \text {-at } \mathrm{L}^{-1} \\
0.03-0.17 \mu \mathrm{g} \text {-at } \mathrm{L}^{-1} \\
0.14 \mu \mathrm{g}-\mathrm{at} \mathrm{\textrm {L } ^ { - 1 }}\end{array}$ & $\begin{array}{l}\text { SE Aegean Sea } \\
\text { Rhodes } \\
\text { Saronikos Gulf }\end{array}$ & $\begin{array}{l}\text { Ignatiades et al., } 1995 \\
\text { Vounatsou \& Karydis } 1991 \\
\text { Ignatiades et al., } 1992\end{array}$ \\
\hline Nitrates & $\begin{array}{l}0.19-0.35 \mu g \text {-at } L^{-1} \\
0.28-0.91 \mu g \text {-at } L^{-1} \\
0.65 \mu g-a t L^{-1}\end{array}$ & $\begin{array}{l}\text { SE Aegean Sea } \\
\text { Rhodes } \\
\text { Saronikos Gulf }\end{array}$ & $\begin{array}{l}\text { Ignatiades et al., } 1995 \\
\text { Vounatsou \& Karydis } 1991 \\
\text { Ignatiades et al., } 1992\end{array}$ \\
\hline Nitrite & $\begin{array}{l}0.02-0.05 \mu g-a t L^{-1} \\
0.03-0.06 \mu g-a t L^{-1} \\
0.16 \mu g-a t L^{-1}\end{array}$ & $\begin{array}{l}\text { SE Aegean Sea } \\
\text { Rhodes } \\
\text { Saronikos Gulf }\end{array}$ & $\begin{array}{l}\text { Ignatiades et al., } 1995 \\
\text { Vounatsou \& Karydis, } 1991 \\
\text { Ignatiades et al., } 1992\end{array}$ \\
\hline Chla & $\begin{array}{l}0.01-5.0 \mu \mathrm{M} \\
0.01-1.7 \mu \mathrm{M} \\
0.03-1.16 \mathrm{mg} \mathrm{m}^{-3} \\
0.07-0.27 \mathrm{mg} \mathrm{m}^{-3}\end{array}$ & $\begin{array}{l}\text { Cretan Sea } \\
\text { Levantine Seas } \\
\text { South Aegean } \\
\text { SE Aegean Sea }\end{array}$ & $\begin{array}{l}\text { Souvermezoglou et al., } 1996 \\
\text { Souvermezoglou et al., } 1996 \\
\text { Ignatiades, } 1998 \\
\text { Ignatiades et al., } 1995\end{array}$ \\
\hline Primary Prod. & $0.135-0.143$ & SE Aegean Sea & Ignatiades, 1998 \\
\hline Phyt. Biomass & $960-9840$ cells $\mathrm{L}^{-1}$ & Rhodes & Karydis \& Tsirtsis, 1996 \\
\hline Secchi disk & $16 \mathrm{~m}$ & Saronikos Gulf & Ignatiades et al., 1992 \\
\hline
\end{tabular}

system's health. The main objective of using environmental indicators is the assessment of ecosystem's integrity. Coastal water are a very dynamic environment since they are influenced by both terrestrial inputs, natural and anthropogenic, as well as from inshore offshore water exchanges, weather conditions and wind - driven water movements. In addition, coastal bathymetry complicates the system response to various inputs. All these physical mechanisms and the fact that nutrient transformations, nutrient uptake and phytoplankton growth proceed at a high rate, suggest that the trophic status of a coastal area should not be considered as an almost static entity (Giovanardi and Vollenweider, 2004). It is therefore obvious that eutrophication indicators should assimilate a large number of data over space and time so that average conditions in the area can be assessed. A good indicator for eutrophication assessment can basically provide information on: (a) to detect trends that cannot be easily observed from the raw data (b) to be used as an early warning system in decision making when management practices are applied and (c) to assess the degree of severity or remediation in areas with established problems of eutrophication. These views for eutrophication indicators are generally consistent with the indicators set by IEFT (EEA, 2005): "an indicator provides a clue to a matter of larger significance or makes perceptiple a trend or phenomenon that is no immediately detectable. An indicator is a sign or symptom that makes something known with a reasonable degree of certainty. An indicator reveals, gives evidence, and its significance extends beyond what is actually measured to a larger phenomenon of interest" In the present work variable indicators, flux indicators as well as community indicators are reviewed. Nutrient concentrations are a common measure in evaluating trophic levels (Ignatiades et al., 1992). Chlorophyll concentrations have been used as a phytoplankton biomass potential both in freshwater (OECD, 1982) and the marine environment (Giovanardi and Tromellini, 1992; Kitsiou and Karydis, 2002).Water transparency usually measured with the Secchi disk can form a scale to characterize trophic conditions.

The most popular flux measurement for assessing eutrophication is primary productivity rates. Measurements are carried out by using the radiocarbon technique (Vollenweider, 1974). The incorporation of ${ }^{14} \mathrm{C}$ labeled bicarbonate $\left(\mathrm{H}^{14} \mathrm{CO}_{3}\right)$ into phytoplanktonic cells is measured. Incubation time in the field varies between 2 to 5 hours and gross primary production that is the total organic matter produced through photosynthesis, before any is lost as respiration. It is well established that changes from oligotrophic to eutrophic conditions induce changes in the community structure of phytoplankton (Gray, 1992; Cloern, 2001). This fact indicates that species indicators assessing the trophic status can be used on their own or in conjunction with variable indices to describe the impact at ecosystem level. The understanding of assemblages of organisms and the way they change in species composition and abundance has always been a question of ecological interest. Since it was realized that pollution was 
inducing qualitative and quantitative changes in species assemblages various formulas based on community structure were evaluated as pollution indicators (Washington, 1984). Species richness, species dominance, species diversity and species resemblance indices were examined in relation to impacts in the marine environment (Wilhm and Dorris, 1968; Danilov and Ekelund, 2001). However, since every community indicator illustrates and emphasizes specific aspects of the community structure the question is twofold: (a) which indicators show sensitivity in marine pollution and (b) which of them can changes monotonously with increasing levels of eutrophication.

It has been pointed out since the early days that increase in nutrient supply bring about a simultaneous increase in diversity (Yourt, 1956; Margalef, 1961). Although it was supported that increases in nutrient concentrations were inducing an increase in diversity (Margalef, 1961), the possible mechanisms were not well understood and the information on the relation between nutrients and diversity index values was rather scanty. Efforts have been reported in literature to select indices for eutrophication assessment (Hooper, 1969; Karydis and Tsirtsis, 1996; Tsirtsis and Karydis, 1998).

In the following sections ten community indices, the most popular for ecological and pollution studies will be presented and evaluated for assessing eutrophic trends.

\section{VARIABLE INDICATORS}

\section{Eutrophication variables: weaknesses and shortcomings}

Eutrophication variables such as nutrient and $\mathrm{chl} \alpha$ concentrations do not seem to follow a linear relationship. It has been established a long time ago (Dugdale, 1967) that nitrogen uptake of phytoplankton and photosynthetic rates follow the Michaelis-Menten equation. This relationship is far from being linear. This is also affecting the scaling of the variable into different trophic levels and therefore a question always comes out: what is the nutrient deviation from reference conditions that produces detectable effects on biomass of phytoplankton as well as on the community structure?

There are two ways to develop a scheme for scaling trophic levels; (a) the a priori data characterization: according to this concept data already collected from various sampling sites have been characterized a eutrophic, mesotrophic and oligotrophic. This empirical approach has been widely applied but there are problems related to the overlapping of these variables; very high values characterizing eutrophic trends and very low values characterizing oligotrophy are usually included in mesotrophic sets of data. It has been reported that this type of overlapping affects the interpretation of the data as well as statistical comparisons among different sites

\section{Nutrients}

A detailed work on nutrient scaling has been carried out by Ignatiades et al. (1992). Three sets of data were used: (a) Inshore water from Saronikos Gulf, an area known as eutrophic (b) offshore Saronikos Gulf water; an area known as mesotrophic with tendencies to oligotrophy and (c) offshore pelagic water from the SE Aegean sea, an area known as oligotrophic (Vounatsou and Karydis, 1991). The data were processed for four variables, phosphates, nitrates, nitrites and ammonia. Outliers were removed from each variable and they were normalized using the Box and Cox transformation. Goodness of fit was tested using the Kolmogorov - Smirnoff test. The transformed data were further analyzed using frequency distribution analysis: the mean $(\mu)$ and standard deviation $(\sigma)$ of the normalized variables were back transformed and the values were used to apply the normal probability function. A linear scaling was adopted $(\mu+\sigma, \mu+2 \sigma, \mu+3 \sigma)$ and the probability of a given value to lie between these limits could be defined. The mean values characterizing trophic levels were: (a) oligotrophic waters: $\mathrm{P}_{-} \mathrm{PO}_{4}: 0.02 \mu \mathrm{M}, \mathrm{N}-\mathrm{NO}_{3}+\mathrm{N}-\mathrm{NO}_{2}: 0.21 \mu \mathrm{M}, \mathrm{N}-\mathrm{NH}_{4}: 0.36 \mu \mathrm{M}$ (b)

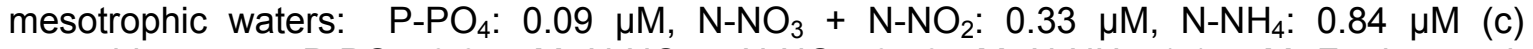
eutrophic waters: $\mathrm{P}_{-} \mathrm{PO}_{4}: 0.34 \mu \mathrm{M}, \mathrm{N}-\mathrm{NO}_{3}+\mathrm{N}-\mathrm{NO}_{2}: 0.53 \mu \mathrm{M}, \mathrm{N}-\mathrm{NH}_{4}: 1.15 \mu \mathrm{M}$. Further work carried out by Ignatiades (2005) including six offshore stations in Northern Aegean, five offshore stations in Southern Aegean and six stations from Saronikos Gulf (3 inshore sites and 3 offshore sampling sites) have provided eutrophication scales based on voluminous data files. Data processing was slightly different to the process described above: outliers were 
removed only when needed and the natural logarithm $(\mathrm{In})$ was used for the normalization of the variables. A nutrient concentration scaling was proposed: (a) oligotrophic waters:

It is obvious that the values characterizing oligotrophy and eutrophication did not differ much in the two publications. A different approach in developing a eutrophication scale was attempted by Stefanou et al. (2000). The approaches presented above are based on an "a priori scaling" of the data since it was assumed that data sets came from areas of known trophic levels. Stefanou et al. (2000) using the same set of data (Ignatiades et al., 1992) applied on an "a posteriori scaling" and using nitrate concentrations produced a physical normal distribution (P-N distribution). The advantage of the method was that the data were rearranged with no parametric techniques using interquartile ranges (IQR) and median values of the inshore and offshore Saronicos Gulf sets of data. This way the natural information was not distorted and a normal curve could be used for probabilistic evaluation of water samples. The mean $\mathrm{P}-\mathrm{N}$ value was $0.32 \mu \mathrm{M} \mathrm{N}-\mathrm{NO}_{3}$ indicating the threshold values between mesotrophic and eutrophic water bodies.

International organizations have proposed nutrient values for assessing eutrophic levels. Their assessments also differ on the calculation of the threshold values: the OECD recommends annual means whereas the CSTT $(1994,1997)$ and OSPAR $(2001,2003)$ proposed seasonal means. The proposed threshold values for phosphorus were: OECD: mean total $\mathrm{P}>35 \mu \mathrm{g} \mathrm{L}^{-1}$ and OSPAR: total inorganic phosphorus (TIP) $>0.8 \mu \mathrm{M}$. Recent work is indicating nutrient values that comply with the requirements of the water Framework Directive, discriminating ecological quality classes (High, Good, Moderate, Poor and Bad). Following a data processing based on log transformation and back-transformation by the exponential function to produce median values for the corresponding log normal distributions, boundary values between ecological quality classes for nutrient variables: phosphate $0.4 \mu \mathrm{M}(\mathrm{H} / \mathrm{G}), 0.8$ $\mu \mathrm{M}(\mathrm{G} / \mathrm{M}), 1.4 \mu \mathrm{M}(\mathrm{M} / \mathrm{P})$ and $2.8 \mu \mathrm{M}(\mathrm{P} / \mathrm{B})$. Nitrate and nitrite: $5 \mu \mathrm{M}(\mathrm{H} / \mathrm{G}), 10 \mu \mathrm{M}(\mathrm{G} / \mathrm{M}), 20$ $\mu \mathrm{M}(\mathrm{M} / \mathrm{P})$ and $40 \mu \mathrm{M}(\mathrm{P} / \mathrm{B})$ and for ammonium: $1 \mu \mathrm{M}(\mathrm{H} / \mathrm{G}), 2 \mu \mathrm{M}(\mathrm{G} / \mathrm{M}), 4 \mu \mathrm{M}(\mathrm{M} / \mathrm{P})$ and $8 \mu \mathrm{M}$ $(\mathrm{P} / \mathrm{B})$. However, this scaling needs testing and possibly adaptations to real conditions. Different water bodies have also been ranked according to their nutrient load using multicriteria choice methods (Moriki and Karydis, 1994). Although these techniques are not a computational tool for scaling trophic status, they can characterize water masses by establishing an hierarchy based on variables describing eutrophication (Karydis, 2005).

Over the last ten years a trophic index known as TRIX was introduced by Vollenweider et al. (1998) for evaluating trophic levels. This index is a linear combination of the logarithm of four variables (Chla, DIN - Dissolved Inorganic Nitrogen, TP = Total Phosphorus and the absolute percentage of deviation from oxygen saturation). This is a composite index that takes into account causes (nutrients), effects (chla) and environmental conditions (oxygen). The proposed eutrophication scaling is: $2<\mathrm{TRIX}<4$ : high, $4<\mathrm{TRIX}<5$ : good, $5<\mathrm{TRIX}<6$ moderate and 6<TRIX<8: poor (Pettine et al., 2007). Although this index has been adopted by the Italian legislation for classification of Italian coastal waters, further work is needed to clarify whether this scale can be accepted at European level or TRIX scales at regional level should be developed.

Another multimetric index based on Principal Component Analysis was proposed by Primpas et al. (2009). This index is a combination of five variables characterizing eutrophication (nitrate, nitrite, ammonia, phosphorus, chlo) and was found efficient in discriminating eutrophic levels as well as thresholds characterizing oligotrophy, mesotrophy and eutrophication.

An index associated with nutrient eutrophication was proposed by Karydis et al. (1983). The index value was calculated by the formula:

$$
I=\frac{C}{C-\log x}+\log A
$$

where $\mathrm{I}$ is the nutrient eutrophication index, $\mathrm{C}$ is the log of the total loading of a given nutrient in the area, $x$ is the total concentration of the nutrient in the area. This way the I value could be calculated for each nutrient and station. $\log A(A=$ the number of stations) was added to make the index independent of the sample size that is the number of stations. Boundary 
values between eutrophic and mesotrophic waters were 4 for phosphate and nitrate and about 5 for ammonia

It has been shown that the elemental atomic ratios in plankton of $\mathrm{O}: \mathrm{C}: \mathrm{N}: \mathrm{P}$ are $276: 106: 16: 1$ respectively (Parsons et al., 1984). Since the N:P ratio 16:1 is maintained under maximal growth rates in nutrient poor waters, steady state conditions are established and therefore the $\mathrm{N}: \mathrm{P}$ ratio $16: 1$, also known as Redfield ratio, is considered as reference value. The relative constancy of the N:P ratio of nutrients is determined by physiological rather than chemical processes. Decreased N:P ratio values indicates nitrogen limitation whereas, higher N:P ratios, potential phosphorus limitation (Redfield et al., 1963). However, it has also been supported that these deviations from the typical $\mathrm{N}: \mathrm{P}$ ratio values can also be linked to eutrophication problems. Changes of the $N: P$ atomic ratio was first related to excessive phosphorus loads from sewage by Ryther and Dunstan (1971).

Ratios of DIN:P (ratio of the total dissolved inorganic nitrogen to dissolved inorganic phosphorus) as well as Si:DIN and Si:P ratios have been used to quantify the impact of riverine waters of the Strymon River on trophic status of the North Aegean Sea (Pavlidou and Georgopoulos, 2001).

\section{Chlorophyll}

Scaling of the chlorophyll variable has been reported by Ignatiades (2005). The sampling area and the data processing were the same as applied in nutrient variables. In the open waters (Aegean Sea) mean values of chla ranged from 0.16 to $0.37 \mathrm{mg} \mathrm{m}^{-3}$ (oligotrophic system), from 0.45 to $0.61 \mathrm{mg} \mathrm{m}^{-3}$ for mesotrophic water type (offshore Saronikos Gulf water) and from 1.16 to $1.84 \mathrm{mg} \mathrm{m}^{-3}$ for the eutrophic water type (inshore Saronikos Gulf Water).

Threshold mean value for chla concentration proposed by OECD (1982) is $>8.0 \mathrm{mg} \mathrm{m}^{-3}$, whereas CSTT proposes summer max chla values $>10 \mathrm{mg} \mathrm{m}^{-3}$.

A chla concentrations scale has been proposed by Karydis (1999) and has been used extensively for the Greek Seas. This scale includes four levels of eutrophication: eutrophic, higher mesotrophic, lower mesotrophic and oligotrophic. The scale was modified by Simboura et al. (2005) to comply with the five levels of ecological status implied by the Water Framework Directive. Simboura et al. (2005) have split the lower mesotrophic range of the Karydis's scale into good water quality $\left(0.1-0.4 \mu \mathrm{g} \mathrm{L}^{-1}\right)$ and moderate water quality $(0.4-$ $\left.0.6 \mu \mathrm{g} \mathrm{L}^{-1}\right)$. A new eutrophication scale based on chl a concentrations was therefore proposed: $<0.1 \mu \mathrm{g} \mathrm{L}^{-1}$ High, $0.1-0.4 \mu \mathrm{g} \mathrm{L}^{-1} \mathrm{Good}, 0.4-0.6 \mu \mathrm{g} \mathrm{L}^{-1}$ Moderate, $0.6-2.21 \mu \mathrm{g} \mathrm{L}^{-1}$ Poor and $>2.21 \mathrm{\mu g} \mathrm{L}^{-1}$ Bad.

Chla scaling can be a promising tool if applied at spatial structures and therefore, heterogeneous water masses can be identified regarding their trophic state (Michelakaki and Kitsiou, 2005).

\section{Phytoplankton abundance}

There is not much work on eutrophication scaling based on phytoplankton cell numbers. However, in published work on spatial analysis it was found that cell number was an efficient variable in studying spatial trends (Kitsiou and Karydis, 2001; Kitsiou and Karydis, 2002). The following scale was proposed: (a) up to $6 \times 10^{3}$ cells $\mathrm{L}^{-1}$ for oligotrophic waters (b) a range from $6 \times 10^{3}$ to $1.5 \times 10^{5}$ cells $L^{-1}$ for mesotrophic waters and (c) more than $1.5 \times 10^{5}$ cells $\mathrm{L}^{-1}$ for eutrophic waters.

\section{Water transparency}

Water transparency measured with the Secchi disk is an easy an inexpensive way to get a rough idea on the trophic situation. Although the Secchi disk is a reliable instrument in offshore waters, shallow coastal waters may introduce significant error to the measurement due to sediment resuspension and terrestrial inputs. The Secchi disk depth for oligotrophic waters varies from 20 to $40 \mathrm{~m}$ (Ignatiades et al., 1995). Secchi readings between 10 and $20 \mathrm{~m}$ characterize mesotrophic conditions whereas the Secchi disk depth for eutrophic waters is less than 10m (Ignatiades et al., 1995). The compensation depth that is the depth where $1 \%$ of the surface radiation is measured has been given for the Aegean waters (Ignatiades, 2005); Northern Aegean 14m (oligotrophic - lower mesotrophic waters), Southern Aegean 
25m (oligotrophic), Saronikos offshore water: $5 \mathrm{~m}$ (upper mesotrophic) and inshore Saronikos Gulf waters $2 \mathrm{~m}$ (eutrophic).

\section{Flux measurements: primary productivity}

Primary productivity rates are also related to trophic levels. According to Ignatiades (2005) primary productivity values range from 0.16 to $0.37 \mathrm{mgC} \mathrm{m}^{-3} \mathrm{~h}^{-1}$ in the Southern and Northern Aegean Sea characterizing oligotrophy; productivity values from 1.37 to $1.58 \mathrm{mgC} \mathrm{m}^{-3} \mathrm{~h}^{-1}$ in the offshore Saronikos Gulf waters characterize mesotrophic conditions and primary productivity values ranging from 3.02 to $4.37 \mathrm{mgC} \mathrm{m}^{-3} \mathrm{~h}^{-1}$ measured in the inshore Saronikos Gulf waters characterize eutrophic conditions.

\section{Oxygen indicators}

Intensified bacterial and animal activity due to increased phytoplankton biomass and high organic loads in eutrophic systems, can lead to oxygen depletion. It is also obvious that indices linked to dissolved oxygen concentrations can be used in simple or composite indices for assessing eutrophic conditions.

Two eutrophication linked indices known as PSA and OXYRISK recently have been proposed. The RSA index that is the "Physically Sensitive Area" index takes into account variables related to eutrophication to identify areas prone to oxygen deficiencies, assuming that primary production and nutrients are evenly distributed.

On the other hand the OXYgen depletion RISK index (OXYRISK) describes spatial distribution potential hypoxia for a given month performing an oxygen budget (Druon et al., 2004). The OXYRISK index represents the probability of oxygen deficiency near the bottom.

The PSA index is based on 3D hydrodynamic models and the OXYDISK index uses satellite derived data. It is therefore doubtful whether they can become popular indices on a routine basis.

\section{ECOLOGICAL INDICATORS}

It has been reported a long time ago (Wilhm and Dorris, 1968) that in spite of the fact that physical and chemical parameters characterizing water quality, there are certain shortcomings as far as the reliability of these variables: numerous chemical substances affect the water quality, sometimes they interact with each other and their concentration ranges usually show wide fluctuations spatial or seasonal. These authors suggested the adoption of water quality criteria based on the assessment of biological conditions. As community structure is rather complex they proposed the use of ecological indicators to assess water quality on the assumption that natural communities form meaningful assemblages. A small number of ecological indicators was then evaluated. As the view that species diversity decreases as environmental pressure increases diversity indices became popular in pollution studies, Shannon's index being "the magic bullet among ecologists" according to Washington (1984). Washington reviewed eighting diversity indices, nineteen biotic indices and five similarity indices and concluded that diversity and similarity indices were rather promising in evaluating water quality. The sensitivity of diversity and similarity indices to monitor community changes induced by pollution was attempted by Boyle et al. (1990). Simulated data were generating using the lognormal distribution representing three hypothetical communities with initial structure of 19,38 and 83 species respectively. An evaluation of the reliability of ecological indices in describing eutrophic trends based on field data from the Aegean Sea was attempted by Karydis and Tsirtsis (1996). Similar methodology was applied to assess the level of eutrophication in Swedish Lakes (Danilov and Ekelund; 1999). Further work was carried out (Tsirtsis and Karydis, 1998) as to the sensitivity of these indices in discriminating between trophic states after application statistical methods. The efficiency of ecological indices was also assessed for coastal waters of Sweden (Danilov and Ekelund; 2001). The suitability of certain ecological indices for assessing eutrophic trends is rather established by now. 


\section{Margalef's Index}

The Margalef's Index $\left(D_{\mathrm{Mg}}\right)$ is a measure of species richness and is based on the presumed linear relation between the number of species and the logarithm of the number of individuals. The index formula is:

$$
D_{M g}=\frac{S-1}{\ln N}
$$

where $\mathrm{N}=$ total number of individuals collected and $\mathrm{S}=$ number of species

Previous work (Karydis and Tsirtsis, 1996) where the consistency of the index was evaluated, Margalef's index was not found appropriate for assessing eutrophic levels since in cluster analysis applied, clusters from oligotrophic and mesotrophic areas were mixed. A confusing pattern due to mixing of sampling sites with different levels of eutrophication was also reported by Danilov and Ekelund (1999).

\section{Menhinick's Index $\left(\mathrm{D}_{\mathrm{Mn}}\right)$}

This is also a well known index (Washington, 1984) expressing species richness. It was assumed that this index showed smaller variation compared to Margalef's Index implying less overlapping between different samples:

$$
D=\frac{S}{\sqrt{N}}
$$

Where $\mathrm{N}=$ total number of individuals collected and $\mathrm{S}=$ the number of species

Menhinick's index was found efficient in evaluating trophic levels (Karydis and Tsirtsis, 1996), although this index does not seem to be in common use in aquatic systems. There is also criticism that Menhinick's index is significantly depended on sample size (Wilhm, 1967). It must also be noticed that Menhinick (1964) neither proposed a relation between this index and the biological system nor suggested how it should be used. Combined application of Menhinick;s index with other ecological indices has been suggested by Danilov and Elelund (2001) as they claim that use of a single index in coastal water eutrophication studies can lead to erratic conclusions.

\section{Kothe's species deficit index $\left(D_{k}\right)$}

This index has been proposed to express the species deficit between a discharge area and a reference sampling point (control site):

$$
D_{k}=\frac{S_{\text {max }}-S}{S_{\max }}
$$

investigation. Balloch et al. (1976) have reported a number of advantages regarding Kothe's index; it gives a percentage linear scale and is useful for indicating the impact from point sources. In spite its simplicity and rational, it has not been used in eutrophication studies and very few workers have used it in ecological and pollution studies. In an evaluation procedure (Karydis and Tsirtsis, 1996) the index was found efficient in assessing eutrophication.

\section{Odum's species index $\left(D_{0}\right)$}

The index expresses the number of species per thousand individuals:

$$
D_{0}=\frac{S \times 1000}{N}
$$

where $\mathrm{N}$ is the total number of individuals and $\mathrm{S}$ the number of species

It has been supported by Washington (1984) that the index has a wide scale for detecting changes due to stress and also that the number of species/ 1000 individuals decreases under polluted conditions. However, this index has limited use in pollution studies (Kitsiou and Karydis, 2000) and no use has been reported on eutrophication assessment although the Odum's index was found efficient in assessing eutrophic levels (Karydis and Tsirtsis, 1996).

Hulbert's encounter index (PIE)

This index was founded on the stability theory. The index's formula is given below:

$$
\mathrm{PIE}=\left(\frac{\mathrm{N}}{\mathrm{N}-1}\right) \times\left(1-\sum_{\mathrm{i}=1}^{\mathrm{S}} \mathrm{pi}^{2}\right)
$$


where $\mathrm{N}$ is the total number of individuals in a population or community and $\mathrm{p}_{\mathrm{i}}$ the fraction of the samples of individuals belonging to species $\mathrm{i}$

Hulbert's (1971) index is based on the idea that each individual in the community can encounter or interact with every other individual in the community (or population). This index has given satisfactory results when evaluated for discriminating between trophic levels. Meso, Oligo and Eutrophic waters were not distinguishable when Hulbert's index was applied by Danilov and Elelund (1999) in Swedish Lakes. Nevertheless, Boyle et al. (1990) had found this index insensitive when it was tested with simulated perturbations. Hulbert's index is rarely used in aquatic studies.

\section{McNaughton's dominance index (I)}

The index expresses the percentage of the two more dominant species in the sample:

$$
\mathrm{I}=\frac{\mathrm{n}_{1}+\mathrm{n}_{2}}{\mathrm{n}} \times 100
$$

where $n_{1}$ and $n_{2}$ are the number of individuals of the two most dominant species and $N$ the total number of individuals in the sample.

McNaughton's index has produced rather confusing results in assessing eutrophication (Karydis and Tsirtsis, 1996). The inefficiency of McNaughton to distinguish between different trophic conditions is also confirmed by Danilov and Ekelund (1999). There has been limited use of the index in eutrophication studies (Ignatiades, 1974; 1977; Friligos and Karydis, 1988).

\section{Simpson's Index $\left(D_{s}\right)$}

$D_{s}$ is a diversity index. What it actually means is the probability of picking two organisms at random that belong to different species (Pielou, 1977). The mathematical formula is given below:

$$
D=\frac{\sum_{i=1}^{s} n_{i} \times\left(n_{i}-1\right)}{n \times(n-1)}
$$

where $n_{i}$ is the number of individuals of the $i^{\text {th }}$ species in the sample and $n$ the total number of individuals in the sample. Although this index is widely accepted it does not seem to be good enough to describe eutrophic conditions based on phytoplankton data and its use for describing eutrophic trends is limited (Sandin and Johnson, 2000; Camargo et al., 2004; Carpenter et al., 2006; Bellinger et al., 2006).

\section{Shannon's index (H')}

It is the most popular diversity index in use by ecologists (Danilov and Ekelund, 2001; Nuccio et al., 2003; Wang et al., 2004; Salas et al., 2006; Bellinger et al., 2006; Simboura and Reizopoulou, 2007). It derives from the information theory and is expressing the average degree of uncertainty in predicting to what species an individual chosen at random from a collection of species S and N individuals will belong to. The formula of Shannon's equation is:

$$
H^{\prime}=-\sum_{i=1}^{S} \frac{n_{i}}{n} \times \ln \frac{n_{i}}{n}
$$

Where $n_{i}$ is the number of individuals of the ith species in the sample and $n$ the total number of individuals in the sample.

Shannon's index has been used to measure "trophic diversity" which meant the diversity of energy moving through in a food web; it has also been interpreted as a measure of stability. Although Shannon's index has often been used in eutrophication studies may be so because of ease of calculation (Valiela, 1984). However, Shannon's index does not seem to be appropriate for eutrophication studies either because of lack of reliability (Karydis and Tsirtsis, 1996) or because this index underestimates the environmental quality of the system (Salas et al., 2006). The last view was also documented after sensitivity analysis (Boyle et al., 1990): shannon's index was found insensitive in simulated perturbations. This index is not recommended for eutrophication studies by Danilov and Ekelund (1999) either. 


\section{Evenness Index (E1)}

This index expresses the degree of equality in species abundance in the sample. The evenness index reaches a maximum value when all species in the sample are equally abundant and decreases towards zero when the relative abundance of the species diverges from evenness (Pielou, 1984).

$$
\mathrm{E} 1=\frac{\mathrm{H}^{\prime}}{\ln \mathrm{S}}
$$

where $H^{\prime}$ is the sample diversity and $\mathrm{H}_{\text {max }}$ the maximum sample diversity. It was found that this index had good performance in discriminating between different levels of eutrophication (Karydis and Tsirtsis, 1996). The evenness index had limited use in the assessment of eutrophication (Lobo et al., 1995; Panayotidis et al., 1999; Kitsiou and Karydis, 2000; Bellinger et al., 2006).

\section{Redundancy Index (R)}

This index is also related to the information theory. Redundancy increases as the information content decreases. It has been reported (Washington, 1984) as a good diversity index since it expresses the distribution of the individuals among species. The redundancy formula is:

$$
\mathrm{R}=\frac{\mathrm{H}^{\prime} \max -\mathrm{H}^{\prime}}{\mathrm{H}^{\prime} \max -\mathrm{H}^{\prime} \min }
$$

where $H^{\prime}$ is the sample diversity, $H_{\text {max }}^{\prime}$ the maximum sample diversity and $H_{\text {min }}^{\prime}$ the minimum sample diversity. Evaluation of the redundancy index in relation to eutrophication (Karydis and Tsirtsis, 1996) did not show very good efficiency of the index applied on phytoplankton communities. However, this index has been used for eutrophication studies of coastal waters on phytoplankton (Gasiunaite et al., 2005; Suikkanen et al., 2007), on invertebrates (Verdonschot, 1996) and ecosystem structure (Weckstrom et al., 2002; Pardall et al., 2004)

\section{DISCUSSION}

Eutrophication of coastal surface waters is the most extensively studied marine pollution problem. Nutrient enrichment is followed by alterations in the phytoplankton community structure, growth of excessive algal biomass and possible toxic algal blooms; if the accumulated organic matter exceeds system's carrying capacity, the hypoxia can lead to a decline in fisheries and shellfisheries yields, poor water quality and ecosystems deterioration. Eutrophication control assumes good knowledge of the dynamics of the phenomenon and ability to carry out comparisons between different sites and thereby to assess the trends in each of these areas (Cognetti, 2001). However, in addition to monitoring variables related to eutrophication, the need for a system development on qualitative- quantitative indicators for assessing the trophic conditions has been stressed (Izzo et al., 1997). In such a dynamic system characterized by fast temporal variations of nutrients and phytoplankton, good eutrophication indices can provide documentation for trophic conditions over a period of time. The indicators should also function as an early warning system for trends of enrichment. Attention is also needed to monitor possible spreading of this phenomenon to formely unaffected areas. It has been pointed out by Hooper (1969) that there is not much value in having indicators that tell us that 'the barn has just burned down'. On the ground of the consideration mentioned above Hooper has proposed that "eutrophication indices should characterize the natural process and assist in measuring instances of relatively slow creeping changes in the ecosystem arising from relatively mild eutrophication". The same author has proposed four criteria for an index characterizing eutrophication levels to be a useful index: (a) Disciminant efficiency; the index should discriminate between changes related to nutrient levels and not with other categories of environmental impacts. The index should also differentiate between changes due to enrichment levels, seasonal effects and changes associated with short term climatic cycles (b) Sensitivity; the index should have considerable sensitivity to the various levels of enrichment; lack of sensitivity would render it inappropriate as an early warning system (c) Geographical distribution; The index properties should be "widespread geographically and short lived geologically". It is advantageous to be able to compare the quality of water masses from various parts of the world using the same index. Also, adoption of an index by national or European legislation assumes the applicability of the 
index over wide geographic areas and (d) Practicality; the index should be suitable for long term monitoring extending over many generations of scientists. Easiness in sampling, simplicity in laboratory analysis and data processing are merits that seriously should be taken into account since the popularity of the index is among the main objectives. In spite of the numerous definitions on eutrophication, they all agree in one point: there is an ecosystem disturbance due to excessive nutrient supply. The use of the "excess" introduces the very serious problem of "normality"; in other words what is the maximum acceptable deviation from "normal values" that would exceed a threshold for each ecosystem. Threshold values vary with geographical areas, distance from the shore, bathymetry, sediment quality and hydrodynamic conditions. Shallow ecosysems are most precarious in nutrient concentration fluctuations since nutrients are stored in sediments and released by resuspension, a process that depends on wave action and circulation patterns. Biogeochemical cycles in the water column and the sediments, especially bacterial biodegradation further complicate the problem of variable fluctuation. In addition to temporal variations and sampling - analytical error add to the uncertainty when trophic status is assessed. It is not therefore always possible to rely on a single variable indicator such as a nutrient variable on chlorophyll concentrations to characterize the trophic conditions of a coastal area. Reliable assessments based on single variable indicators can be carried out only if long term measurements of nitrogen, phosphorus and chlorophyll concentrations are available. The contribution to the assessment of eutrophication, of historical data, is twofold: (a) threshold values can be established and (b) the fluctuation mentioned above can be leveled off and therefore the assessment can express ecosystem status over a sizable period of time. The development of the TRIX index seems to give an answer to the shortcomings due to the use of univariate procedures: being a linear combination of four state variables, integrates interactions between pressures (nitrogen and phosphorus inputs), state (chlorophyll concentrations and primary productivity rates) and impact (oxygen depletion affecting biological properties).

The need for using diversity indicators to evaluate ecosystem disturbance has been proposed since sixties (Wilhm and Dorris, 1968). This is because chemical substances with adverse effects on the biotic elements of the ecosystem can be numerous and if interactions (positive or negative) are to be taken into account, the impact assessment is both complicated and dubious. Using ecological indices the problem focuses on the impact which is ecosystem's health. In the case of eutrophication, detection of biological responses can give an evidence concerning specific nutrient thresholds; it has already been reported that nutrient enrichment alone, in a given water body, is not possible to determine specific nutrient thresholds (Devlin et al., 2007). On the other hand the effects of ecosystem reactions can be detected on a series of biological effects that can be integrated and summarized in an ecological indicator. As the ecological indices are mathematical expressions of ecological trends, they can be used for statistical comparisons. In spite of the widely accepted view that ecological indices could be useful tools in pollution studies (Wilhm and Dorris, 1968; Haedrick, 1975; Washington, 1984) they had not been evaluated for eutrophication studies until much later (Karydis and Tsirtsis, 1996; Tsirtsis and Karydis, 1998; Danilov and Ekelund, 1999; 2001). As the problem of eutrophication became among the main concerns of the European Environment Agency and the need set by the Water Framework Directive for water quality indicators has brought up the issue "for developing a system of qualitative - quantitative indicators for assessment of the trophic situation based on historical records of the observed biological effects" (Izzo et al., 1997). The evaluation of eutrophication indices for assessing trophic status showed that popular indices such as the Shannon's index were not suitable for quantifying eutrophic trends. More work is needed on other indices that have not been used much in aquatic systems and they seem to be promising in assessing eutrophication. Although there is still ongoing research in eutrophication indices, the objective set by the Water Framework Directive to develop an indicator system at a European level seems to be near completion as far as eutrophication assessment if concerned.

\section{REFERENCES}

Archibald R.E.M. (1972) Diversity in some South African diatom associations and its relation to water quality, Water Research, 6, 1229-1238. 
Balloch D., Dames C.E. and Jones F.H. (1976) Biological assessment of water quality in the three British Rivers the North Esk (Scotland), the Ivel (England) and the Taf (Wales), Water Pollution Control, 75, 92-114.

Bechtel T.J. and Copelend B.J. (1971) Fish species diversity indices as indicators of pollution in Galveston Bay, Texas, Contributions in Marine Science, 15, 103-132.

Bellinger B.J., Cocquyt C. and O'Reilly C.M. (2006) Benthic diatoms as indicators of eutrophication in tropical streams, Hydrobiologia, 573, 75-87.

Boyle T.P., Smillie G.M., Anderson J.C. and Beeson D.R. (1990) A sensitivity analysis of seven diversity and seven similarity indexes, Research Journal of the Water Pollution Control Federation, 62, 749-762.

Camargo J.A., Alonso A. and De la Puente M. (2004) Multimetric assessment of nutrient enrichment in impounded rivers based on benthic macroinvertebrates, Environmental Monitoring and Assessment, 96, 233-249.

Carpenter K.E., Johnson J.M. and Buchanan C. (2006) An index of biotic integrity based on the summer polyhaline zooplankton community of the Chesapeake Bay, Marine Environmental Research, 62, 165-180.

CSTT (1994) Comprehensive studies for the purpose of Article 6 of DIR 91/271 EEC. The Urban Waste Water Treatment Directive. Published for the Comprehensive Studies Task Team of Group Coordinating Sea Disposal Monitoring by the Forth River Publication Board, Edinburgh.

CSTT (1997) Comprehensive studies for the purposes of the Article $6 \& 8.5$ of DIR 91/271 EEC. The Urban Waste Water Treatment Directive, second edition. Published by the Comprehensive Studies Task Team of Group Coordinating Sea Disposal Monitoring by the Department of the Environment of Northern Ireland, The Environment Agency, the OAERRE page 40 version of: July 4, 2002 Scottish Environmental Protection Agency and the Water Services Association, Edingurgh.

Cloern J.E. (2001) Our evolving conceptual model of the costal eutrophication problem, Review, Marine Ecology Progress Series, 210, 223-253.

Cognetti G. (2001) Marine eutrophication: the need for a new indicator species, Marine Pollution Bulletin, 42, 163-164.

Cook S.E.K. (1976) Quest of an index of community structure sensitive to water pollution, Environmental Pollution, 11, 269-288.

Costanza R. (1992) Towards an operational definition of health, In: Ecosystem health = New goals for environmental management, Costanza, R., Norton, B. and Haskell B.D. (Eds.), Island Press, Washington, DC, pp.239-256.

Danilov R.A. and Ekelund N.G.A. (1999) The efficiency of seven diversity and one similarity indices based on phytoplankton data for assessing the level of eutrophication in lakes of central Sweden, The Science of the Total Environment, 234, 15-23.

Danilov R.A. and Ekelund N.G.A. (2001) Comparative studies on the usefulness of seven ecological indices for the marine coastal monitoring close to the shore on the Swedish East coast, Environmental Monitoring and Assessment, 66, 265-279.

Devlin M., Painting D. and Best M. (2007) Setting nutrient thresholds to support an ecological assessment based on nutrient enrichment, potential primary production and undesirable disturbance, Marine Pollution Bulletin, 55, 65-73

Druon J.N., Schrimpf W, Dobricic S and Stips A. (2004) Comparative assessment of large-scale marine eutrophication; North Sea area and Adriatic Sea as case studies. Marine Ecology Progress Series, 272, 1-23.

Dugdale R.C. (1967) Nutrient limitation in the sea. Dynamics, Identification and Significance, Limnology and Oceanography, 12, 685-695.

EEA (2005) European Environment Agency: core set of indicators. Guide, Technical Report No.1/2005, 38pp.

European Commission (2007) Environmental Marine Information System. Joint Research Center, Institute for Environment and Sustainability. 6 December 2008, http:/emis.jrc.ec.europa.eu/

Friligos, N. and Karydis M. (1988) Nutrients and phytoplankton distributions during spring in the Aegean Sea, Vie Milieu, 38, 133-143.

Gasiunaite Z.R., Cardoso A.C., Heiskanen A.S., Heiskanen A.S., Henriksen P., Kauppila P., Olenina I., Pilkaityte R., Purina I., Razinkovas A., Sagert S., Schubert H. and Wasmund N. 
(2005) Seasonality of coastal phytoplankton in the Baltic Sea: influence of salinity and eutrophication, Estuarine Coastal and Shelf Science, 65, 239-252.

Giovanardi F. and Tromellini E. (1992) Statistical assessment of trophic conditions. Application of the OECD methodology to the marine environment, In: Marine Coastal Eutrophication, Vollenweider R.A., Marchetti R. and Viviani R. (eds.), Elsevier, London, pp. 211-233.

Giovanardi F. and Vollenweider R.A. (2004) Trophic conditions of marine coastal waters: experience in applying the Trophic Index TRIX to two areas of the Adriatic and Tyrrhenian seas, Journal of Limnology, 63, 199-218.

Gotsis-Skretas O., Pagou K., Moraitou-Apostolopoulou M. and Ignatiades L. (1999) Seasonal horizontal and vertical variability in primary production and standing stocks of phytoplankton and zooplankton in the Cretan Sea and the Straits of the cretan Arc (March 1994 - January 1995), Progress in Oceanography, 44, 625-649

Gray S.J. (1992) Eutrophication in the sea, in G. Colombo and R. Viviani (Eds), Marine Eutrophication and Pollution Dynamics, Olsen \& Olsen, Fredensborg, 394p.

Haedrick R. (1975) Diversity and overlap as measures of environmental quality, Water Research, 9, 945-949.

Hooper F.F. (1969) Eutrophication indices and their relation to other indices of ecosystem change. In: Eutrophication: Causes, consequences and correctives, pp. 225-235. National Academy of Sciences, Washington, DC.

Hurlbert S.H. (1971) The non concept of species diversity: a critique and alternative parameters, Ecology, 59, 67-77

Ignatiades L. (1974) The phytoplankton distribution in a tidal area, Botanica Marina, XVII, 55-59.

Ignatiades L. (1976) The standing stock of diatoms and dinoflagellates in the oligotrophic waters of Southern Aegean Sea, Int. Rev. Gesamten Hydrobiol., 61, 193-199.

Ignatiades L. (1977) Ecological responses of phytoplankton on chronic oil pollution, Environmental Pollution, 13, 109-118.

Ignatiades L. (1998) The productive and optical status of the oligotrophic waters of the Southern Aegean Sea (Cretan Sea), Eastern Mediterranean, Journal of Plankton Research, 20, 985995.

Ignatiades L. (2005) Scaling the trophic status of the Aegean Sea, eastern Mediterranean, Journal of Sea Research, 54, 51-57.

Ignatiades L., Karydis M. and Vounatsou P. (1992) A possible method for evaluating Oligotrophy and Eutrophication based on nutrient concentrations, Marine Pollution Bulletin, 24(5), 238243.

Ignatiades L., Georgooulos D. and Karydis M. (1995) Description of a phytoplanktonic community of the oligotrophic waters of SE Aegean Sea (Mediterranean), P.S.Z.I. Mar. Ecol., 16, 13-26.

Izzo G., Silvestri C., Creo C. and Signorini A. (1997) Is nitrate an oligotrophic factor in Venice Lagoon ?, Marine Chemistry, 58, 245-253.

Janssen R. (1992) Multiobjective decision support for Environmental Management. Kluwer Acedemic Publishers, Dordrecht, 232pp.

Karydis M. (1999) Evaluation report on the eutrophication level in coastal Greek areas. University of the Aegean, Mytilini, February 1999 (in Greek)

Karydis M. (2001) Assessing levels of eutrophication : A short review on quantitative methodology, Biologia Gallo- Hellenica, 27, 135-144.

Karydis M. (2005) Understanding marine eutrophication from agricultural runoff in semi enclosed areas: a presentation of quantitative methodology, Global Nest Journal, 7(2), 228-235.

Karydis M., Ignatiades L. and Moschopoulou N. (1983) An index associated with nutrient eutrophication in the marine environment, Estuarine, Coastal and Shelf Science, 16, 339-344.

Karydis M. and Tsirtsis G. (1996) Ecological indices: a biometric approach for assessing eutrophication levels in the marine environment, The Science of the Total Environment, 186, 209-219.

Kimor B. and Wood E.J.F. (1975) A plankton study in the Eastern Mediterranean, Marine Biology, 29, 321-333.

Kitsiou D. and Karydis M. (1998) Development of categorical mapping for quantitative assessment of eutrophication, Journal of Coastal Concervation, 4, 33-44.

Kitsiou D. and Karydis M. (2000) Categorical mapping of marine eutrophication based on ecological indices, The Science of Total Environment, 255, 113-127. 
Kitsiou D. and Karydis M. (2001) Marine eutrophication: a proposed data analysis procedure for assessing spatial trends, Environmental monitoring and Assessment, 68, 297-312.

Kitsiou D. and Karydis M. (2002) Multi- dimensional evaluation and ranking of coastal areas using GIS and multiple criteria choice methods, Science of the Total Environment, 284, 1-17.

Krom M.D., Kress N. and Brenner S. (1991) Phosphorus limitation of primary productivity in the eastaern Mediterranean, Limnology and Oceanography, 36, 424-432.

Legendre L. and Legendre P. (1983) Numerical Ecology, Elsevier, N.Y.

Liddel H.G. and Scott R. (1907) Great Dictionary of the Greek Language (Greek translation), I. Sideris Publications, Athens.

Lobo E.A., Katoh K. and Aruga Y. (1995) Response of epilithic diatom assemblages to water pollution in rivers in the Tokyo metropolitan area, Japan, Freshwater Biology, 34, 191-204.

Ludwig J.A. and Reynolds J.F. (1988) Statistical ecology: a primer on methods and computing, Wiley, N.Y.

Magurran A.E. (2004) Measuring biological diversity, Blackwell Publishing, 256pp.

Margalef R. (1961) Communication of structure in planktonic populations, Limnology and Oceanography, 6, 124-128.

Menhinick E.P. (1964) A comparison of some species-individuals diversity indices applied to samples of field insects, Ecology, 45, 859-861.

Michelakaki M., and Kitsiou D. (2005) Estimation of anisotropies in chlorophyll a spatial distributions based on satellite data and variography, Global Nest Journal, 7, 204-211.

Mihnea P.E. (1985) Phytoplankton diversity indices as eutrophication indicators of the Romanian inshore waters, Cercerati Marine, I.R.C.M., 18, 139-155.

Moriki A. and Karydis M. (1994) Application of the multi criteria choice methods in assessing eutrophication. Environmental Monitoring and Assessment, 33, 1-18.

Nixon S.W. (1995) Coastal marine eutrophication: a definition, social causes and future concerns, Ophelia, 41, 199-219.

Nuccio C., Melillo C., Massi L. and Innamorati M. (2003) Phytoplankton abundance, community structure and diversity in the eutrophicated Orbetello lagoon (Tuscany) from 1995 to 2001, Oceanologica Acta, 26, 15-25.

OECD (1982) Eutrophication of Water, Monitoring Assessment and Control. Organization of Economic Co-operation and Development, Paris.

OSPAR (2001) Draft common assessment criteria and their application within the comprehensive procedure of the common procedure. Meeting of The Eutrophication Task Group, London, 911 October 2001. Ospar Convention for the Protection of the Marine Environment of the North- East Atlantic.

OSPAR (2003) Strategies of the OSPAR Commission for the protection of the Marine Environment of the North - East Atlantic (Reference number 2003-21) In: OSPAR Convention for the protection of the marine environment of the North East Atlantic: Ministerial Meeting of the OSPAR Commission Bremen: 25 June 2003 Vol. Annex 31 (Ref. B-4.2).

Panayotidis P., Feretopoulou J. and Montesanto B. (1999) Benthic vegetation as an ecological quality descriptor in an Eastern Mediterranean coastal area (Kalloni Bay, Aegean Sea, Greece), Estuarine Coastal and Shelf Science, 48, 205-214.

Pardal M.A., Cardoso P.G., Sousa J.P., Marques J.C. and Raffaelli D. (2004) Assessing environmental quality: a novel approach, Marine Ecology - Progress Series, 267, 1-8.

Parsons T.R., Takahashi M. and Hargrave B. (1984) Biological Oceanic Processes, 3rd ed. Pergamon Press, Oxford.

Pavlidou A. and Georgopoulos G. (2001) Dissolved oxygen and nutrients in coastal waters impacted by the Strymon River plume, North Aegean, Greece, Global NEST: the Int. Journal, 3(2), 71-84.

Pettine M., Casentini B., Fazi S., Giovanardi F. and Pagnota R. (2007) A revisitation of TRIX for trophic status assessment in the light of the European Water Framework Directive: Application to Italian coastal waters, Marine Pollution Bulletin, 54, 1413-1426.

Pianka E.R.(2000) Evolutionary ecology, Pearsing Education, Inc.

Pielou E.C. (1977) Mathematical ecology. J. Wiley \& Sons, N.Y.

Pielou E.C. (1984) Ecological Diversity, J. Wiley \& Sons, 165pp

Redfield A.C., Ketchum B.H. and Richards F.A. (1963) The influence of organisms on the composition of seawater. In The Sea, Vol. 2 (edited by Hill M.N.) pp. 26-77. Wiley Interscience, New York. 
Rodhe W. (1969) Crystallization of eutrophication concepts in Northern Europe. In: Eutrophication: Causes, consequences and correctives, pp.50-64. National Academy of Sciences, Washington, DC.

Primpas I., Karydis M. and Tsirtsis G. (2008) Assessment of clustering algorithms in discriminating eutrophic levels in coastal waters, Global Nest Journal, 10(3), 359-365.

Primpas I., Tsirtsis G., Karydis M. and Kokkoris G. (2009) Principal Component Analysis: development of a multivariate index for assessing eutrophication according to the European Water Framework Directive, Ecological Indicators, doi 10.1016/j.ecolind.2009.04007.

Primpas I. and Karydis M. (2009) Improving statistical distinctness in assessing trophic levels: the development of simulated normal distributions, Environmental Monitoring and Assessment, doi 10.1007/s10661-009-1177-1.

Ryther J.H. and Dunstan W.M. (1971) Nitrogen, phosphorus and eutrophication in the coastal marine environment, Science, 171, 1008-1013

Salas F., Patricio J. Marcos C., Pardal M.A., Perez-Ruzafa A. and Marques J.C. (2006) Are taxonomic distinctness measures compliat to other ecological indicators in assessing ecological status?, Marine Pollution Bulletin, 52, 162-174.

Sandin L. and Johnston R.K. (2000) The statistical power of selected indicator metrics using macroinvertebrates for assessing acidification and eutrophication of running waters, Hydrobiologia, 422, 233-243.

Simboura N., Panayotidis P. and Papathanassiou E. (2005) A synthesis of the biological quality elements for the implementation of the European Water Framework Directive in the Mediterranean ecoregion: the case of Saronikos Gulf, Ecological Indicators, 5, 253-266.

Simboura N. and Reizopoulou S. (2007) A comparative approach of assessing ecological status in two coastal areas of Eastern Mediterranean, Ecological Indicators, 7, 455-468.

Souvermezoglou E., Krasakopoulou E. and Pavlidou A. (1999) Temporal variability in oxygen and nutrient concentrations in the Southern Aegean and the Straits of the Cretan Arc, Progress in Oceanography, 44, 573-600.

Steele J.H. (1974) The structure of marine ecosystems. Harvard Univ. Press, Cambridge, 128pp.

Stefanou P., Tsirtsis G. and Karydis M. (2000) Nutrient scaling for assessing eutrohication: the development of a simulated normal distribution, Ecological Applications, 10, 303-309.

Suikkanen S., Laamanen M. and Huttunen M. (2007) Long term changes in summer phytoplankton communities of the open northern Baltic Sea, Estuarine Coastal and Shelf Science, 71, 580-592.

Tsirtsis G. and Karydis M. (1998) Evaluation of phytoplankton community indices for detecting eutrophic trends in the marine environment, Environmental Monitoring and Assessment, 50, 255-269.

UN (1984) Coastal area management and development (United Nations Department of International and Social Affairs), Pergamon Press, Oxford 188pp.

Valiela I. (1984) Marine Ecological Processes, Springer-Verlag N.Y.

Verdonschot P.F.M. (1996) oligochaetes and eutrophication; an experiment over four years in outdoor mesocosms, Hydrobiologia, 334, 169-183.

Vollenweider R.A. (1974) A manual of methods measuring Primary Production in aquatic Envirnments IBP, Blackwell Scientific Publications, Oxford, 225pp.

Vollenweider R.A., Marchetti R. and Viviani R. (eds.) (1992) Marine Coastal Eutrophication, Elsevier, London.

Vollenweider R.A. (1992) Coastal Marine Eutrophication: principles and control pp.1-20, In: Marine Coastal Eutrophication, Vollenweider R.A., Marchetti R. and Viviani R. (eds.), Elsevier, London.

Vollenweider R.A., Giovanardi F. Montanari G. and Rinaldi A. (1998) Chracteriazion of the trophic conditions of marine coastal waters with special reference to the NW Adriatic Sea: proposal for a trophic scale, turbidity and generalized water quality index, Environmetrics, 9, 329-357.

Vounatsou P. and Karydis M. (1991) Environmental characteristics in oligotrophic waters. Data evaluation and statistical limitations in water quality studies, Environmental Monitoring and Assessment, 18, 211-220.

Wang Z.H., Matsuoka K., Qi Y.Z., Chen J.F. and Lu S.H. (2004) Dinoflagellate cyst records in recent sediments from Daya Bay, South China Sea, Phycological Research, 52, 396-407.

Washington H.G. (1984) Diversity, biotic and similarity indices. A review with special relevance to aquatic ecosystems, Water Research, 18, 653-694. 
Weckstrom K., Korhola A. and Shemeika P. (2002) Physical and chemical characteristics of shallow embayments on the Southern coast of Finland, Hydrobiologia, 477, 115-127.

Wilhm J.L. (1967) Comparison of some diversity indices applied to populations of benthic macroinvertebrates in a stream receiving organic wastes, Journal of Water Pollution Control Federation, 42, 221-224.

Wilhm J.L. and Dorris G.T. (1968) Biological parameters for water quality criteria, BioScience, 18, 477-481.

Yount J.L. (1956) Factors that control species number in Silver Springs, Florida, Limnology and Oceanography, 1, 286-295. 